\title{
Translational research at acute HIV Infection
}

\author{
Jean Pierre Routy \\ From $16^{\text {th }}$ International Symposium on HIV and Emerging Infectious Diseases \\ Marseille, France. 24-26 March 2010
}

The initial interaction between HIV and its host is crucial in determining disease progression and uniquely provides the ability to explore the determinants of HIV acquisition. Upon this first encounter, the virus will induce an innate and adaptive immune response that will determine the severity of symptoms and the level of $\mathrm{T}$ cell activation. To rationally design the optimal treatment strategy, whether it immunotherapies or ART, this brief time period is of the utmost importance. The challenge here lies in the conflict between the drive for scientific knowledge and supporting the patient though this emotional stage. However, only a delicate balance between these necessities will produce successful translational research. In addition, integrating virological, immunological and behavioural factors has become the sole valid approach of properly addressing both HIV pathogenesis and patient needs.

After two decades of HIV research, mucosa immunity has emerged as a cornerstone of future research. Several studies in both SIV and HIV infection have emphasized the importance of depletion of mucosal CD4 T cells and high levels of $\mathrm{T}$ cell activation immediately following infection. The contribution of mucosal immunity has shed light on the importance $\alpha 4 \beta 7$ mucosal homing receptors, massive loss of memory $\mathrm{CD} 4 \mathrm{~T}$ cells, microbial translocation, and $\mathrm{T}$ cell activation. Recently, dendritic cells, monocytes, NK cells as well as the interleukin-7 and interleukin-21 signalling pathways have been shown to contribute to the early immune dysfunction observed after infection. The timing of ART initiation plays a major role on the quality of immune recovery. In addition, the establishment of viral reservoir occurs within days after infection and its size is largely determined by the CD4 memory/effector ratio and CD4 cell nadir.

New frontiers in acute HIV infection research need to include blood sampling by leukapheresis to collect large quantities of immune cells, mucosa biopsies, and

McGill University, Montreal, Canada

BioMed Central @ 2010 Routy; licensee BioMed Central Ltd. neurocognitive evaluation to pave the route toward HIV eradication and rational design of vaccines and immunotherapies.

Published: 11 May 2010

doi:10.1186/1742-4690-7-S1-I18

Cite this article as: Routy: Translational research at acute HIV Infection. Retrovirology 2010 7(Suppl 1):I18.
Submit your next manuscript to BioMed Central and take full advantage of:

- Convenient online submission

- Thorough peer review

- No space constraints or color figure charges

- Immediate publication on acceptance

- Inclusion in PubMed, CAS, Scopus and Google Scholar

- Research which is freely available for redistribution

Submit your manuscript at www.biomedcentral.com/submit
C Biomed Central 